\title{
PELATIHAN INTERNET BANKING DAN MOBILE BANKING BAGI GURU PEMASARAN SERTA PELAKU UKM DI WILAYAH SURABAYA
}

\author{
Sadana Devica \\ Politeknik Ubaya \\ Email: sadana.devica@staff.ubaya.ac.id
}

\begin{abstract}
Internet banking and mobile banking training for marketing teachers and small and medium enterpries (SMEs) in the Surabaya region is one form of community service activities carried out by the Ubaya Polytechnic Marketing Management Study Program. This activity is carried out with the aim to provide participants with insights on how to use internet banking and mobile banking. This training was held on July 6, 2019 at Ubaya Polytechnic Campus Surabaya, which was attended by 38 participants. The method used in this training is to socialize how to use internet banking or mobile banking as a payment transaction tool that is often used today. The results achieved from this training activity are that participants can utilize existing technology, especially in the banking sector more effectively.
\end{abstract}

Keyword: training, internet banking, mobile banking.

\section{PENDAHULUAN}

Seiring dengan kemajuan teknologi yang begitu pesat, maka aktivitas pemasaran pun juga mengalami benyak sekali perubahan dari kegiatan yang dilakukan secara konvensional saat ini telah berubah menjadi aktivitas-aktivitas digital yang erat sekali dengan penggunanaan gadget dan internet. Aktivitas pemasaran juga harus menjangkau khalayak yang lebih luas dan dapat dilakukan kapan saja serta di mana saja untuk menunjang keberhasilan penjualan. Di era digital ini pelaku usaha selain harus mampu membuat rencana bisnis yang baik, mereka dituntut pula untuk mengikuti perkembangan teknologi agar bisnis yang mereka lakukan mampu bersaing dan bertahan dalam jangka panjang. Oleh karena itu, menyusun rencana bisnis yang baik dan ditunjang dengan penggunaan marketplace serta transaksi pembayaran secara online diharapkan mampu meningkatkan daya saing pelaku UKM dalam mengembangkan usahanya.

Menurut Tan dan Teo (2000) internet banking merupakan salah satu fasilitas perbankan dengan memanfaatkan teknologi internet untuk memberikan kemudahan bagi nasabahnya untuk melakukan transaksi keuangan tanpa harus datang ke kantor bank atau antri di mesin ATM. Jika ditinjau dari fungsi atau keguanaannya, internet banking ataupun mobile banking ini memiliki banyak sekali fitur-fitur yang bisa membuat aktivitas perbankan menjadi lebih mudah dan cepat. Namun, tidak semua masyarakat khususnya pelaku UKM atau guru pemasaran menggunakan fasilitas tersebut meskipun mereka telah memiliki akses internet dan menggunakan smartphone. Alasan mengapa mereka tidak menggunakan internet banking ataupun mobile banking adalah karena mereka tidak memahami bagaimana cara menggunakannya dan mereka ragu tentang faktor keamanan apabila bertransaksi menggunakan internet banking atau mobile banking. Di sisi lain peserta pelatihan, khususnya bagi pelaku UKM, menyadari betul bahwa sebenarnya dengan menggunakan internet banking atau mobile banking dapat mendukung aktivitas transaksi penjualan online mereka di e-commerce. Dengan menggunakan internet banking atau mobile banking peserta bisa memantau trasaksi penjualan, melakukan transfer, bahkan melakukan pembayaran kapan saja dan di mana 
saja. Selain itu, internet banking atau mobile banking tidak dikenakan biaya berlangganan. Pengguna hanya diminta untuk mengunduh aplikasi jika ingin menggunakan mobile banking di smartphone, melakukan aktivasi di mesin ATM dan melakukan validasi user ID dan angka PIN atau password di customer service pada bank tempat membuka rekening.

Tujuan dari pelaksanaan kegiatan pengabdian kepada masyarakat ini adalah untuk memberikan pemahaman bagaimana cara menggunakan internet banking serta mobile banking secara aman guna mendukung kegiatan penjualan pelaku UKM melalui $e$ commerce. Selain itu, kegiatan ini diharapkan juga mampu memberikan tambahan wawasan bagi guru pemasaran di SMK sehingga materi yang diperoleh selama mengikuti pelatihan ini nantinya bisa diberikan kepada para siswa sebagai tambahan ilmu dan penunjang mata pelajaran inti di sekolah.

\section{METODE}

Adapun metode pada pelatihan ini dibagi menjadi 3 (tiga) sesi materi, yaitu tahap pertama adalah mengenalkan internet banking dan mobile banking, tahap kedua adalah bagaimana cara menggunakan internet banking dan mobile banking, serta tahap yang ketiga adalah keamanan dalam bertransaksi dengan menggunakan internet banking dan mobile banking. Ketiga metode pelatihan secara ringkas dapat dilihat pada Gambar 1 berikut ini:

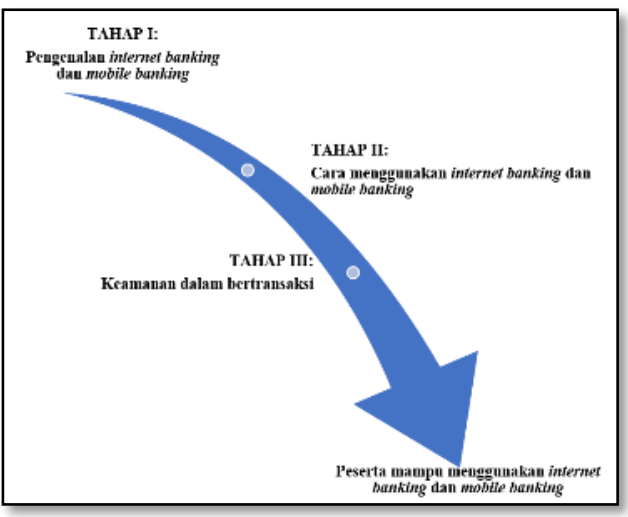

\section{Gambar 1: Metode Pelaksanaan Pelatihan Internet Banking dan Mobile Banking}

Adapun masing-masing tahapan akan dijelaskan sebagai berikut:

\section{Tahap I:}

Pada tahap ini peserta pelatihan diperkenalkan dengan situs internet banking, aplikasi mobile banking serta bagaimana cara mengaksesnya. Hal pertama yang harus dilakukan untuk bisa mengakses internet banking atau mobile banking adalah peserta harus mendaftar melalui mesin ATM dengan memilih menu aktivasi internet banking dan mobile banking. Setelah melakukan aktivasi melalui ATM, maka tahap selanjutnya adalah pengguna harus datang ke customer service kantor cabang terdekat untuk membuat PIN atau password dan untuk mendapatkan token. Token digunakan untuk mendapatkan kombinasi angka unik yang akan digunakan pada saat melakukan transaksi (transfer atau pembayaran). 


\section{a) Pengenalan internet banking}

Untuk menggunakan internet banking peserta hanya perlu membuka situs atau laman website resmi bank melalui browser yang ada di komputer atau laptop, sebagai contoh:

- BCA situs yang bisa diakses adalah https://ibank.klikbca.com/

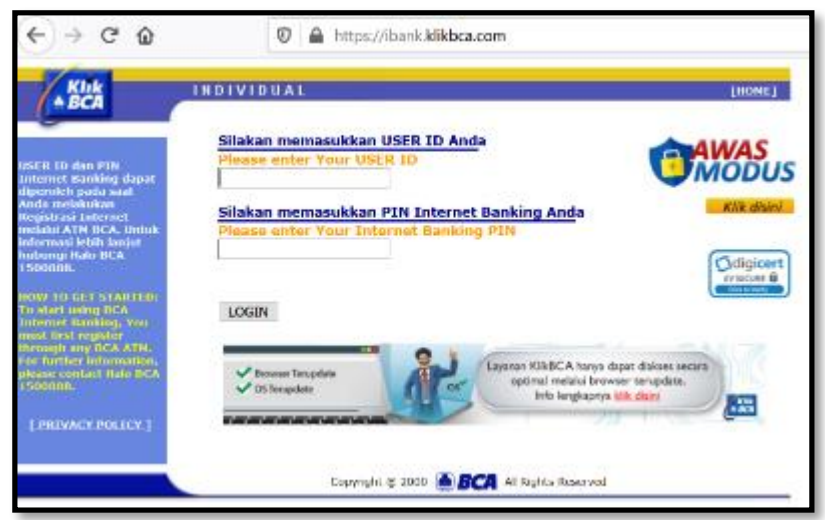

Gambar 2: Situs Internet Banking BCA

- CIMB Niaga situs yang bisa diakses adalah https://www.cimbclicks.co.id/ibcimbniaga/Login.html

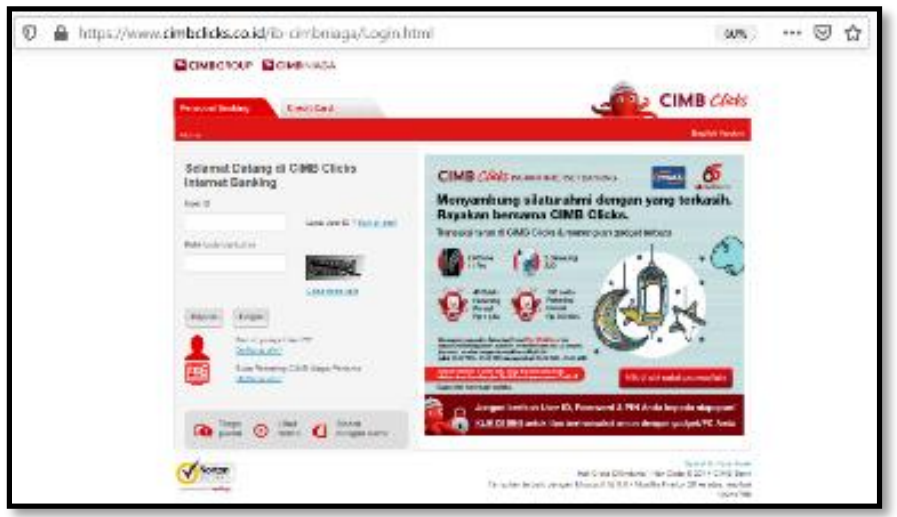

Gambar 3: Situs Internet Banking CIMB Niaga

Kedua situs tersebut digunakan pada pelatihan hanya sebagai contoh agar peserta bisa mempraktikan secara langsung bagaimana mencari dan membuka laman situs website internet banking melalui browser. Nantinya peserta bisa menyesuaikan dengan membuka situs internet banking sesuai dengan bank tempat peserta menempatkan dana atau tabungannya.

\section{b) Pengenalan mobile banking}

Untuk mengakses mobile banking peserta diberikan pelatihan bagaimana cara mengunduh aplikasi di smartphone masing-masing dengan langkah-langkah sebagai berikut: 
- Seluruh peserta pelatihan menggunakan smartphone Android sehingga untuk mengunduh aplikasi mobile banking yang diinginkan, peserta bisa mencarinya pada aplikasi Play Store.

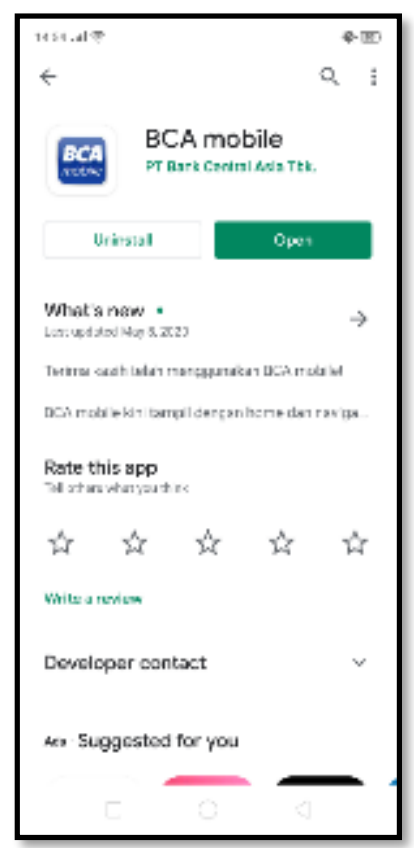

\section{Gambar 4: Contoh Aplikasi Mobile Banking BCA}

- Setelah aplikasi mobile banking yang diinginkan selesai diunduh, maka peserta bisa langsung menggunakan fitur-ditur yang ada pada aplikasi tersebut. Peserta bisa mengunduh lebih dari satu aplikasi mobile banking sesuai dengan kebutuhan atau refensi bank masing-masing. Aplikasi mobile banking yang ada di Play Store bisa diunduh secara gratis dan tidak dipungut biaya berlangganan.

\section{Tahap II:}

Pada tahap kedua ini peserta diberikan pelatihan bagaimana cara menggunakan internet banking dan mobile banking. Setelah melakukan aktivasi di mesin ATM dan membuat PIN atau password di customer service, maka peserta bisa melakukan login pada internet banking atau mobile banking. Adapun fitur layanan yang dapat digunakan apabila peserta telah memiliki user ID serta password atau PIN untuk login meliputi fasilitas cek saldo, transfer, pembayaran, top up e-wallet, tarik tunai atau setor tunai tanpa menggunakan kartu ATM, dan masih banyak lagi fasilitas lainnya tergantung pada aplikasi bank masing-masing. Bagi pelaku usaha / bisnis UKM biasanya fitur yang paling sering diguanakan adalah cek saldo, transfer dan pembayaran. Dengan memanfaatkan fitur-fitur yang ada di internet banking atau mobile banking akan memudahkan pelaku usaha untuk melakukan cek mutasi rekening dengan cepat tanpa harus antri di mesin ATM atau datang ke kantor bank untuk cetak mutasi rekening. Hal tersebut tentunya akan sangat membantu pelaku usaha apabila mereka ingin memastikan apakah pembayaran yang dilakukan oleh customer mereka telah dintransferkan atau belum. Selain itu, apabila pengguna ingin melakukan pembayaran atau transfer ke pemasok atau vendor juga bisa 
dilakukan secara real time (saat itu juga) melalui internet banking atau mobile banking. Berikut adalah contoh fitur-fitur yang ada di internet banking atau mobile banking:

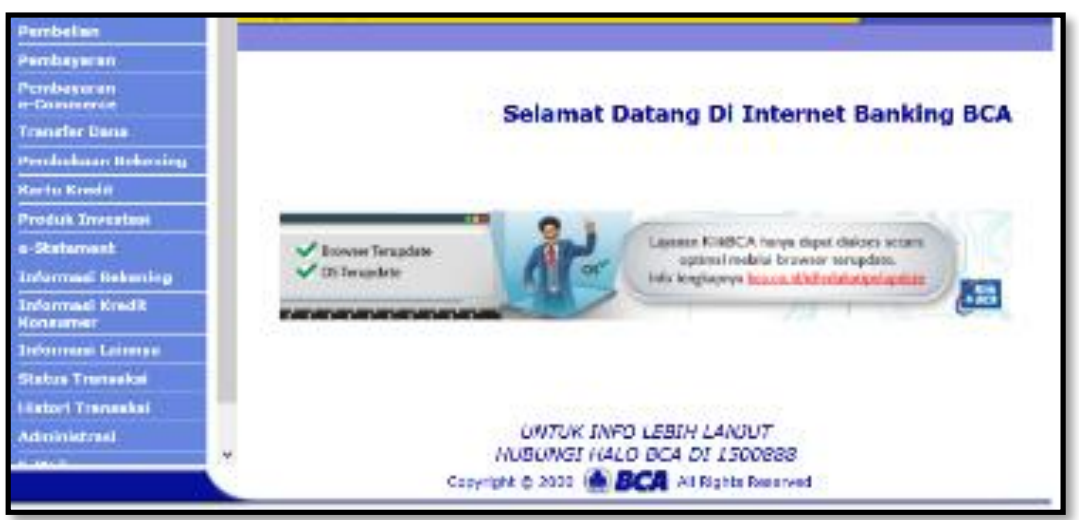

Gambar 5 Contoh Fitur Layanan Internet Banking BCA

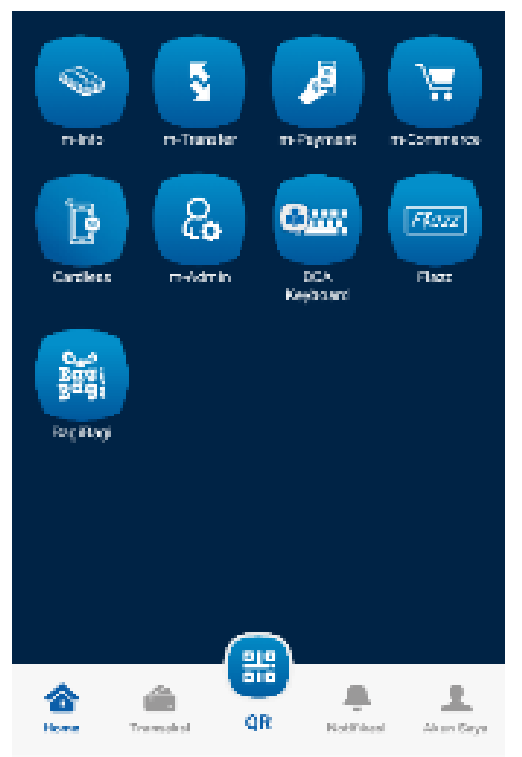

\section{Gambar 6: Contoh Fitur Layanan Mobile Banking BCA}

Secara umum fitur menu layanan pada internet banking atau mobile banking adalah sama. Hanya tampilannya saja yang berbeda karena untuk internet banking pengguna mengaksesnya melalui laptop atau komputer sedangkan untuk mobile banking pengguna mengaksesnya dengan menggunakan smartphone. Selain itu, fitur layanan yang ditawarkan oleh bank selain BCA secara garis besar sama, yaitu fasilitas cek saldo, transfer, pembayaran, top up e-wallet, tarik tunai atau setor tunai tanpa menggunakan kartu ATM, dan masih banyak lagi fasilitas lainnya. Jadi, peserta tidak perlu bingung apabila menggunakan internet banking atau mobile banking selain dari BCA karena cara login dan pengoperasiannya pun sama.

\section{Tahap III:}


Pada pelatihan sesi ketiga ini dijelaskan mengenai bertransaksi yang aman dengan menggunakan internet banking atau mobile banking. Pada tahap awal dan kedua banyak sekali peserta yang memang ragu dan masih bingung mengenai kemanan dalam menggunakan internet banking atau mobile banking. Namun, sistem kemanan yang terdapat pada internet banking atau mobile banking tentunya sudah sangat baik dan terenkripsi. Oleh sebab itu di tahap awal pengguna internet banking atau mobile banking harus datang ke customer service untuk membuat user ID dan password atau PIN untuk bisa menngunakan layanan ini. Beberapa bank juga masih menggunakan token seperti yang terlihat pada Gambar 7 yang digunakan untuk menghasilkan kombinasi angka unik untuk melakukan transaksi keuangan.

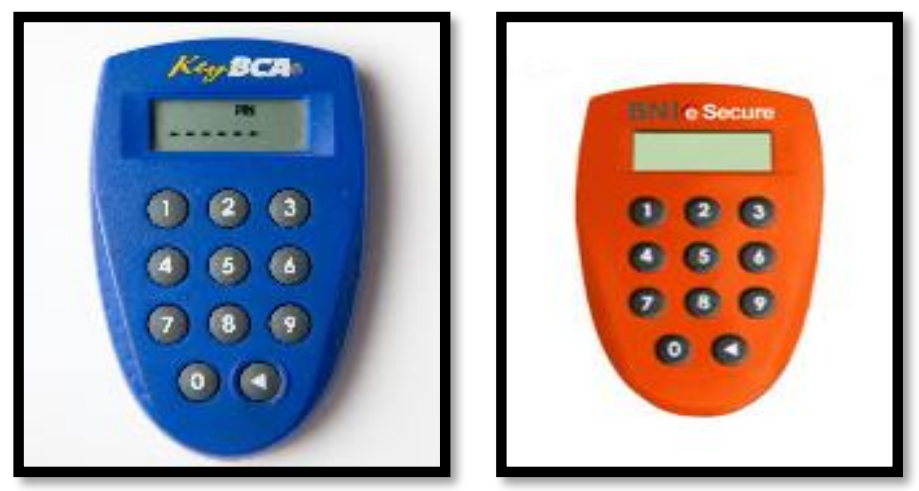

Gambar 7: Contoh Token

Token ini berfungsi untuk mengeluarkan PIN atau kombinasi angka per tiap kali transaksi yang dilakukan dengan menggunakan internet banking. Namun, tidak semua bank menggunakan token. Apabila customer service tidak memberikan token, maka onetime password (OTP) per tiap kali transaksi yang akan dilakukan akan dikirimkan melalui sms ke nomer handphone yang terdaftar. Selain itu, beberapa tips aman dalam bertransaksi menggunakan internet banking atau mobile banking juga dijelaskan kepada peserta pelatihan yang meliputi:

a) Membuat user ID dan PIN yang tidak mudah ditebak orang lain (bukan merupakan tanggal lahir atau angka yang berurutan).

b) Rahasiakan PIN dari siapapun pada saat melakukan transaksi. Bank juga tidak pernah meminta informasi seperti kode akses, PIN atau password.

c) Jangan melanjutkan transaksi ketika menemukan ketidakwajaran atau hal yang mencurigakan pada internet banking.

d) Jika terdapat transaksi yang mencurigakan, segera hubungi call center bank.

e) Lindungi komputer/laptop dengan anti virus, spyware filter, filter email, dan program firewall.

f) Pastikan akses situs website bank sudah benar dan jangan klik alamat website dengan kata yang berbeda/salah ejaan meskipun mirip dengan yang asli.

g) Hindari menggunakan jaringan internet gratis (free wifi) untuk melakukan transaksi.

h) Jangan memberitahukan kode transaksi one-time password (OTP) kepada siapa pun.

\section{HASIL KARYA UTAMA DAN PEMBAHASAN}


Kegiatan pengabdian kepada masyarakat dalam bentuk pelatihan ini memberikan wawasan baru bagi guru pemasaran dan pelaku UKM di wilayah Surabaya. Pelatihan yang diselenggarakan pada tanggal 6 Juli 2019 bertempat di kampus Politeknik Ubaya dan dihadiri oleh 38 orang peserta. Bidang usaha yang digeluti oleh peserta mayoritas adalah makanan dan aksesoris dengan omset rata-rata tiga juta rupiah per bulannya. Berdasarkan hasil observasi dan wawancara pada saat kelas pelatihan berlangsung mayoritas peserta masih melakukan penjualan secara konvensional dan tidak pernah menggunakan fasilitas internet banking atau mobile banking sebelumnya. Jadi metode pembayaran yang dilakukan selama ini hanya dengan uang tunai serta penjualan hanya dilakukan secara tatap muka langsung. Dengan mengikuti pelatihan ini, maka peserta telah memiliki pemahaman dan mampu:

1) Mengakses internet banking atau mobile banking.

2) Memanfaatkan fitur dan layanan yang ada di internet banking atau mobile banking.

3) Bertransaksi secara aman dengan menggunakan internet banking atau mobile banking.

Selain itu, setelah mengikuti pelatihan ini peserta bisa memulai untuk melakukan penjualan secara online melalui sosial media atau e-commerce karena mereka telah memahami bagaimana cara bertransaksi dengan menggunakan internet banking atau mobile banking. Dengan memahami materi pelatihan ini peserta UKM nantinya bisa memparaktikkan atau mengimplementasikan metode penjualan yang lebih modern, kemudian bisa menjangkau target pasar yang lebih luas, serta meraih omset penjualan yang semakin meningkat. Kendala-kendala yang dulu mereka hadapi atau khawatirkan, seperti bagaimana memantau transaksi penjualan apabila mereka ingin melakukan penjualan secara online telah teratasi karena perserta telah memperoleh wawasan secara lengkap tentang fungsi dan manfaat dari internet banking atau mobile banking. Peserta juga akan lebih percaya diri untuk memajukan usahanya dan termotivasi untuk mengelola keuangan usaha dengan lebih profesional.

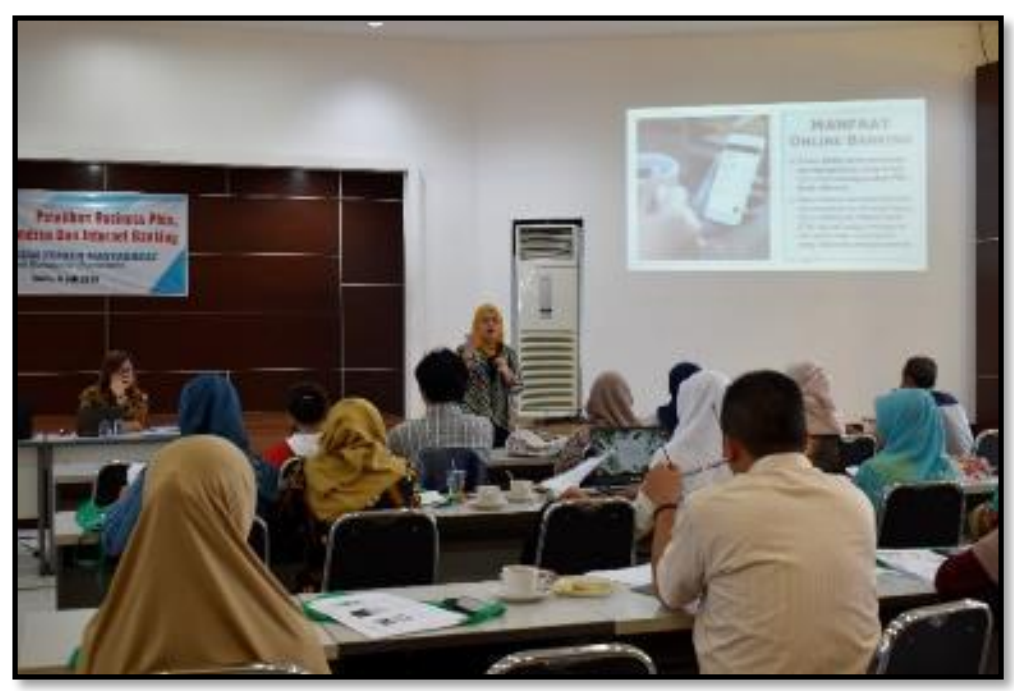




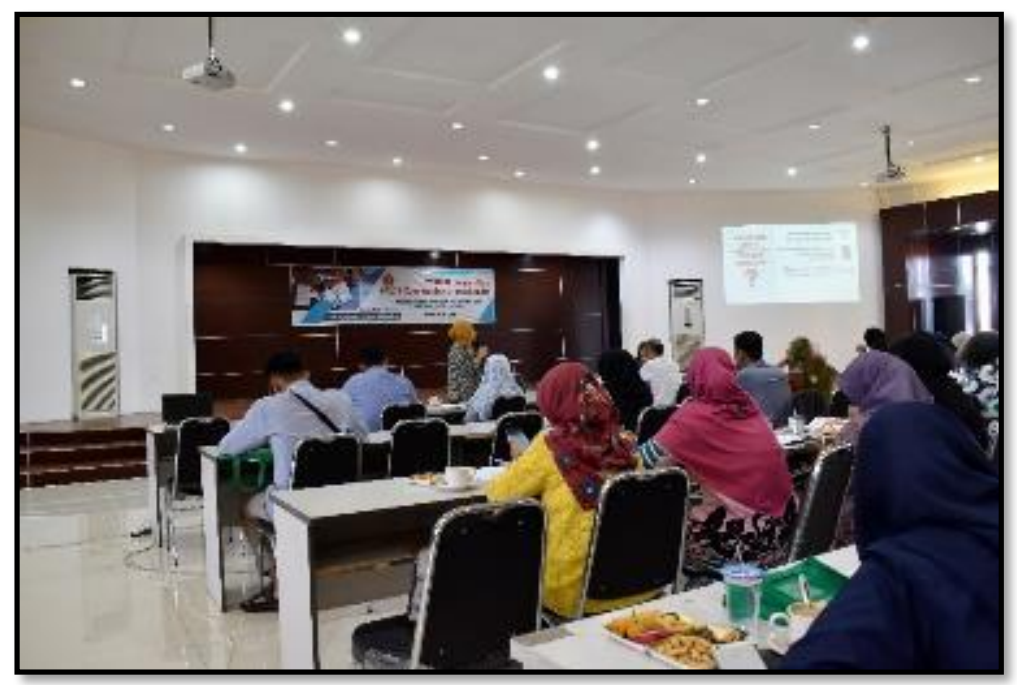

\section{Gambar 8: Suasana Kelas Pelatihan Internet Banking Dan Mobile Banking}

Selanjutnya, bagi peserta guru pemasaran wawasan tentang internet banking atau mobile banking nantinya dapat diinformasikan sebagai materi atau tambahan wawasan bagi siswa SMK karena tren finance technology (FinTech) dewasa ini sangat berkembang pesat terutama sejak munculnya $e$-wallet. E-wallet sendiri mulai banyak digunakan karena di Indonesia layanan jasa online dan e-commerce mulai bertumbuh. Hal ini menyebabkan metode transaksi pembayaran secara konvensional mulai menurun dan berubah menjadi metode pembayaran yang dilakukan secara digital. Kaum milenial atau yang kita kenal dengan generasi $\mathrm{Z}$ merupakan mayoritas pengguna dari transaksi digital, sehingga pengetahuan wawasan tentang internet banking atau mobile banking perlu juga disosialisasikan kepada siswa SMK sebagai tambahan wawasan di bidang digitalisasi perbankan dan mereka bisa mengikuti tren transaksi keuangan saat ini.

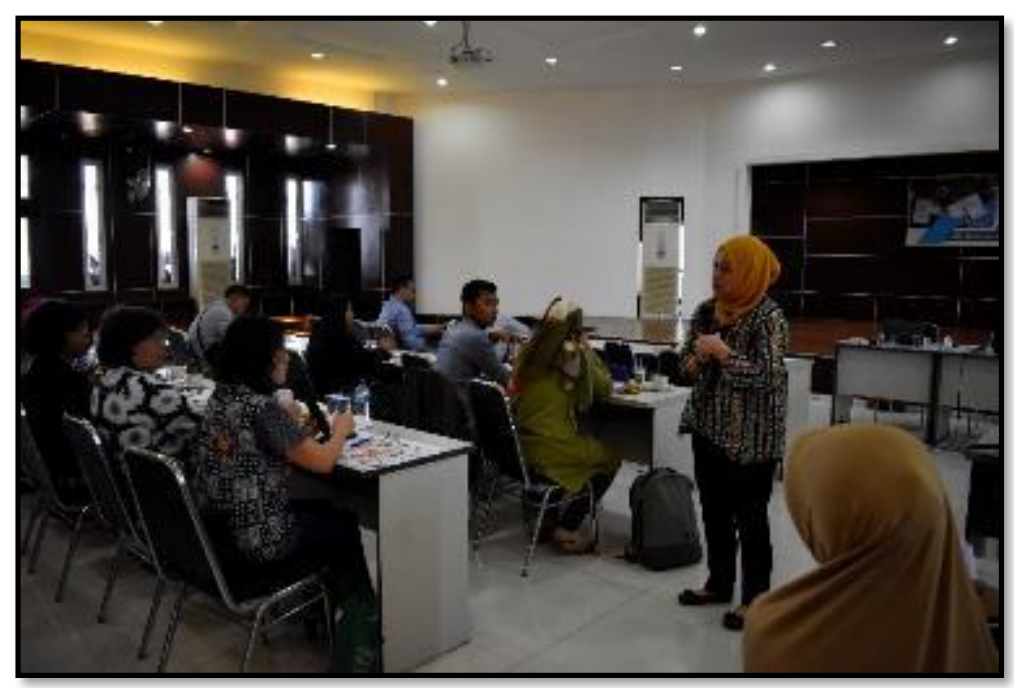




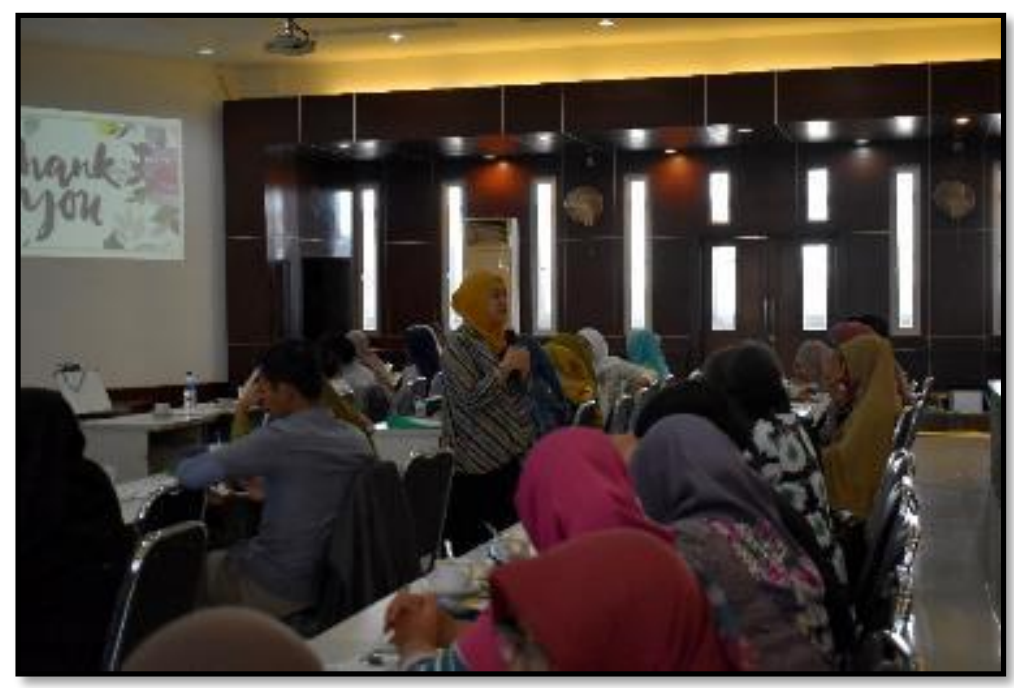

Gambar 9: Suasana Sesi Tanya Jawab Dengan Peserta Pelatihan

Di samping itu internet banking atau mobile banking sebenarnya tidak hanya digunakan untuk kepentingan transaksi keuangan bisnis saja namun juga bisa digunakan untuk transaksi keuangan individu sehari-hari seperti transfer, pengisian saldo $e$-wallet, pembayaran tagihan listrik dan air. Jadi, internet banking atau mobile banking bisa digunakan oleh siapa saja yang membutuhkan metode transaksi keuangan yang cepat dan aman. Gagasan dilakukannya kegiatan pengabdian kepada masyarakat ini muncul juga dikarenakan masih banyak sekali masyarakat khususnya pelaku UKM dan guru pemasaran yang belum mengenal tentang digitalisasi perbankan. Padahal transaksi perbankan pasti kita lakukan dikehidupan sehari-hari. Digitalisasi perbankan masih dianggap sebagai suatu metode yang menyulitkan bagi masyarakat yang awam tentang cara pengoperasiannya, sehingga masyarakat menjadi enggan untuk menggunakannya dan menganggap bahwa cara lama yang mereka lakukan selama ini, seperti antri di mesin ATM atau datang ke kantor cabang merupakan cara yang paling mudah dan aman. Di samping itu, jaman saat ini semakin berkembang dan canggih. Banyak sekali aktivitas di kehidupan kita menjadi berubah akibat kemajuan teknologi dan penggunaan internet, misanya masyarakat sudah mulai terbiasa dengan belanja online dan menggunakan digital money. Perubahan dari dua aspek itu saja dapat menyebabkan pola transaksi keuangan kita menjadi berubah. Oleh karena itu, perubahan jaman terutama di bidang digitalisasi perbankan harus mampu diadaptasi oleh masyarakat terutama pelaku UKM agar pengeleloaan keuangan usaha menjadi lebih baik dan mampu bersaing di dunia bisnis.

\section{KESIMPULAN}

Kegiatan pengabdian kepada masyarakat dalam bentuk pelatihan internet banking dan mobile banking bagi guru pemasaran dan pelaku UKM di wilayah Surabaya ini memberikan wawasan dan pemahaman kepada peserta tentang apa itu kegunaan internet banking dan mobile banking, bagaimana cara menggunakan internet banking dan mobile banking, dan terakhir adalah bagaimana cara bertransaksi yang aman dengan menggunakan internet banking dan mobile banking. Masih banyak masyarakat dan pelaku UKM yang belum menggunakan internet banking dan mobile banking meskipun mereka memiliki akses internet dan menggunakan smartphone. Kendala yang dihadapi 
adalah kurangnya pemahaman mereka tentang bagaimana cara pengoperasian internet banking atau mobile banking serta kekhawatiran tentang masalah keamanan dalam bertransaksi. Dengan dilakukannya pelatihan ini, maka dapat memberikan wawasan dan pemahaman kepada masyarakat tentang keunggulan dan manfaat menggunakan internet banking dan mobile banking, baik untuk kepentingan pengelolaan keuangan usaha atau untuk keperluan transaksi perbankan sehari-hari. Perkembangan teknologi dan penggunaan internet telah merubah metode transaksi perdagangan sehingga saat ini masyarakat harus mampu beradaptasi dengan perubahan tersebut.

\section{DAFTAR PUSTAKA}

Ikatan Bank Indonesia, 2013, Memahami Bisnis Bank (Modul Sertifikasi Tingkat I General Banking LSPP - IBI), Edisi I, Jakarta: Penerbit PT Gramedia Pustaka Utama.

Kasmir, 2015, Dasar-Dasar Perbankan, Edisi Revisi 13, Jakarta: Rajawali Pers.

Tan, M. dan Teo, T. S.H., 2000, Factors Influencing the Adoption of Internet Banking, Journal of the Association for Information Systems, Vol. 1 No. 5, hlm. 1-44 